ISSN 1112-9867

http://www.jfas.info

\title{
RICH EXTRACT ON TOTAL POLYPHENOLS AND ANTIOXIDANT ACTIVITY OBTAINED BY CONVENTIONAL AND NON-CONVENTIONAL METHODS FROM AHMEUR BOUAMER GRAPE SEED
}

\author{
Z. Ghouila ${ }^{1,2,}$, S. Laurent ${ }^{3}$, C. Henoumont ${ }^{3}$, L. Vander Elst ${ }^{3}$, R. N. Muller ${ }^{3,4}$, A. \\ Baaliouamer $^{2}$
}

\begin{abstract}
${ }^{1}$ Scientific and Technical Research Center in Physical and Chemical Analysis (CRAPC), B.P 248 Alger RP 16004 Algiers, Algeria

${ }^{2}$ USTHB, Organic Functional Analysis Laboratory, 16111 Bab Ezzouar, Algiers, Algeria

${ }^{3}$ Department of General, Organic and Biomedical Chemistry, NMR and Molecular Imaging

Laboratory, University of Mons, Avenue Maistriau, 19, Mendeleiev Building, Belgium

${ }^{4}$ Center for Microscopy and Molecular Imaging, Académie Wallonie- Bruxelles, Gosselies, Belgium
\end{abstract}

Received: 04 March 2016 / Accepted: 06 August 2016 / Published online: 01 Septembre 2016

ABSTRACT: Conventional and non-conventional extraction methods were applied in the first time for the determination of total polyphenols from Ahmeur Bouamer, an anthoctonous variety grape seeds. Independently of the time and temperature, a positive effect of particle size parameter on maceration has been noted and relativly high concentrations in polyphenols for $500 \mathrm{~m}(67.78 \pm 0.46 \mathrm{mg} \mathrm{GAE} / \mathrm{gdm}), 500-355 \mathrm{~m}(90.95 \pm 0.24 \mathrm{mg} \mathrm{GAE} / \mathrm{gdm})$ and $355-180 \mu \mathrm{m}(114.82 \pm 1.24 \mathrm{mg} \mathrm{GAE} / \mathrm{gdm})$ have been obtained. The higher value of yield was reached by the microwave extraction $(37.74 \pm 0.32 \%)$, followed by the maceration $(14.16 \pm 0.15 \%)$ and the ultrasound $(6.70 \pm 0.25 \%)$. The appropriate extraction method to obtain a relatively strong antioxidant activity from seeds was the microwave with inhibition of $69.67 \pm 1.76 \%$ and $78.05 \pm 2.05 \%$ of $\mathrm{DPPH}$ and $\mathrm{ABTS}^{+}$free radicals, respectively.

Keywords: Ahmeur Bouamer, extraction, grape seeds, total polyphenols, antioxidant activity.

Author Correspondence, e-mail: zghouila@yahoo.com

doi: http://dx.doi.org/10.4314/jfas.v8i3.3 


\section{INTRODUCTION}

The interest carried to the active components like polyphenols has greatly increased in recent years. These compounds are known as good natural antioxidant agents arising from natural sources (fruits, vegetables, plants etc.) and can be an alternative to synthetic antioxidants used in food and pharmaceutical industry like BHA and BHT, which their undesirable effect on health was often revealed [1]. Among the widely consumed fruits which are considered as an excellent source of polyphenols, the grapevine is the favorite. All the parts of grape contain polyphenols but $60-70 \%$ of extractible polyphenols are concentrated in seeds [2], as monomeric, dimeric, trimeric and tetrameric phenolic compounds [3]. To achieve these rich extracts in polyphenols, it is important to develop efficient methods of extraction leading to quite best yields. Conventional method such as maceration, used for a long time [4], is still relevant even if it is often criticized for its extraction time (few hours) and high temperature (over $80{ }^{\circ} \mathrm{C}$ ). Some authors improve continually this technique by varying the extraction parameters (type of solvent, liquid / solid ratio, etc.) in order to reduce the extraction time and the temperature $[2,5,6]$. The introduction of non-conventional methods such as ultrasound and microwave has revolutionized the extraction by reducing significantly the extraction time and increasing the yield [7].The use of ultrasound waves to heat the matrix increases the contact surface between solid and liquid phases; this is mainly due to the dispersion of the particle [8]. The heating of the matrix internally and externally without thermal gradient gives numerous advantages to microwave extraction, including a shorter time (few seconds), less solvent used, a higher extraction rate and less polarity limitation for the extractant [9]. In this present work and for the first time, the autochthonous variety Ahmeur Bouamer, targeted by the development of grape planting in Algeria has been chosen to extract total polyphenols from seeds. This variety of the species Vitis vinifera $\mathrm{L}$ from Medea region is one of the varieties that have the advantage of seniority and local attributes "mountain-Piedmonts." [10,11]. Total polyphenols were extracted by maceration, ultrasound and microwave, after the optimization of the extraction conditions by focusing on the positive role played by the particle size on the extraction efficiency. A tentative explanation has been advanced for the understanding of the structural changes inherent in the extraction of polyphenols from secreting cells by scanning electron 
microscopy images of different particle sizes, before and after extraction. The comparison of these extraction methods was performed and the obtained results were also compared with those cited by previous works. The quality of the different extracts was assessed by evaluation of radical scavenging activities (\% inhibition of $\mathrm{DPPH}^{\cdot}$ and $\mathrm{ABTS}^{\cdot+}$ free radicals).

\section{MATERIALS AND METHODS}

\subsection{Chemicals}

All aqueous solutions used for extraction were prepared by using ultra-pure water by Milli-Q System (Millipore). Chemicals have analytical grade, Folin \& Ciocalteu reagent F9252 (Sigma-Aldrich), gallic acid for analysis (UCB, Belgium), ethanol absolute (CHEM-LAB), extra pure sodium carbonate decahydrated $\left(\mathrm{Na}_{2} \mathrm{CO}_{3} \quad 10 \mathrm{H}_{2} \mathrm{O}\right)$ (Merck), 2-2'Azinobis (3-ethylbenzothiazoline-6-sulphonic acid) diammonium salt $\left(\mathrm{ABTS}^{\cdot+}\right)$,

1,1-diphenyl-2-picrylhydrazyl (DPPH') persulfate $\left(\mathrm{K}_{2} \mathrm{~S}_{2} \mathrm{O}_{8}\right)$, butylhydroxytoluene (BHT) and butylhydroxyanisole (BHA) (Sigma-Aldrich).

\subsection{Preparation of grape seed extracts}

\subsubsection{Plant material}

Ahmeur Bouamer grapes were harvested in September 2010 at Benchicao in Medea hills (80Km South of Algiers) with the collaboration of the Technological Institute of Fruit Arboriculture and Vine. The storage and transport conditions have been respected $\left(\right.$ at $8^{\circ} \mathrm{C}$ in coolers). Once in laboratory, the clusters were washed with distilled and de-ionized water, then dried and stored at $-20^{\circ} \mathrm{C}$ in the freezer. Grape seeds were removed from berries, weighted, washed and dried between two filter papers for 24 hours and weighted again. The dry seeds were ground into a fine powder and stored hermetically at $4^{\circ} \mathrm{C}$ prior to use.

\subsubsection{Sieve analysis and dry matter content}

Grape seeds were ground in a grinder ultracentrifuge (ZM 200, Retsch) with ring sieve of 500 $\mu \mathrm{m}$. The powder was placed in a sieve shaker (A200 Digit Retsch) in a decreasing aperture size order and the sieves (seed powder) were shaken for $10 \mathrm{~min}$. Different portions size were selected. Dry matter content of grape seeds was determined by drying at $105^{\circ} \mathrm{C}$ to constant mass in triplicate (Table 1). 


\subsection{Extraction methods}

\subsubsection{Maceration}

In the first time, the milled powder given by sieve analysis was used to optimize various parameters of maceration extraction (Table 1). In the second time the grape seeds were milled with ring sieve of $250 \mu \mathrm{m}$ and used to compare the three studied extraction methods in the same conditions. Ethanol is a good solvent for the extraction of polyphenols from grape seeds and gives a lower toxicity relative to methanol, which provides nearly the same results [12]. The use of aqueous ethanol improves the solubility of the bioactive components, the optimum mixture composition being 50/50 v/v, which is the most cited composition in previous works $[13,5,6]$. All the extractions were done in triplicate.

\subsubsection{Determination of ethanol / water composition}

In test tubes, $0.5 \mathrm{~g}$ of milled grape seeds was mixed with $10 \mathrm{~mL}$ of various ethanol / water solvent compositions $(25 / 75,50 / 50,75 / 25$ and 90/10 v/v, respectively) (test tubes were covered with aluminum foil to avoid light) at $25^{\circ} \mathrm{C}$ during 120 min with 20 s shaking each test tubes at $15 \mathrm{~min}$ intervals by Vortex.The ethanolic extract was centrifuged for $20 \mathrm{~min}$ on 3500 $\mathrm{g}$ at $20^{\circ} \mathrm{C}$ and then filtered on Whatman filter paper $\# 4$ (9.0 cm diameter). The extract volume was measured, brought up to $25 \mathrm{~mL}$ with aqueous ethanol solution of different composition and stored at $-20^{\circ} \mathrm{C}$.

\subsubsection{Determination of ratio Liquid/Solid (L/S)}

In the test tubes, $0.5 \mathrm{~g}$ of powder grape seeds (size 500-355 $\mu \mathrm{m}$ ) was mixed with 5, 10, 15 and $20 \mathrm{~mL}$ of $50 \%$ aqueous ethanol to obtain $\mathrm{L} / \mathrm{S}$ ratios of $10,20,30$ and $40 \mathrm{~mL} / \mathrm{g}$, respectively. Test tubes were conserved at $25^{\circ} \mathrm{C}$ during 120 min with 20 s shaking by Vortex of each test tube at 15 min intervals. The ethanolic extracts were prepared as described previously.

\subsubsection{Optimization of time, temperature and particle size}

The higher total polyphenol content was obtained with the ratio $20 \mathrm{~mL} / \mathrm{g}$ (Fig.1B). This ratio was thus used for this study. Three particle sizes were used: $>500 \mu \mathrm{m}, 500-355 \mu \mathrm{m}$ and $355-180 \mu \mathrm{m}$. For each particle size, the extraction was carried out for 30, 60, 120 and $180 \mathrm{~min}$ at different temperatures $\left(25^{\circ} \mathrm{C}, 50^{\circ} \mathrm{C}\right.$ and $\left.80^{\circ} \mathrm{C}\right)$. The extraction was done as described previously. SEM analysis of the milled grape seeds of different particle sizes were achieved 
before and after the maceration extraction method. The powder was mounted on SEM stubs. The specimens were metalized on high vacuum evaporator MED020 (Leica). The observations were performed with an ESEM Quanta 200 FEG (Tecnai) microscope. Images were analyzed and processed by AnalySIS software.

\subsubsection{Ultrasound}

In the ultrasonic bath (BRANSON 3210, work frequency of $47 \mathrm{KHz} \pm 6 \%$, power supply of $335 \mathrm{~W}$ and output power of $105 \mathrm{~W})$, test tubes of $0.5 \mathrm{~g}$ of powder seeds $(<250 \mu \mathrm{m})$ mixed with ethanol/water $50 / 50$ in liquid solid ratio of $20 \mathrm{~mL} / \mathrm{g}$ were immersed at $25^{\circ} \mathrm{C}$. The extraction was performed for a time of 5, 15, 30 and $60 \mathrm{~min}$. Extracts were prepared in the same way as described previously.

\subsubsection{Microwave}

Extractions were performed on an analytical microwave (CEM Discover, Co, USA) with a regulator of temperature and pressure and a cooling system. Time and temperature were optimized. $0.5 \mathrm{~g}$ of grape seed powder $(<250 \mu \mathrm{m})$ was put into a $100 \mathrm{~mL}$ flask connected to a refrigerant and mixed with ethanol/water 50/50 in liquid solid ratio of $20 \mathrm{~mL} / \mathrm{g}$. The mixture was stirred under an open system. Extraction was performed at times of 2.5, 5, 15, 30 and 60 min and at different temperatures $\left(25^{\circ} \mathrm{C}, 50^{\circ} \mathrm{C}\right.$ and $\left.80^{\circ} \mathrm{C}\right)$. The preparation of extracts was similar to that used previously.

\subsection{Determination of total polyphenols}

Total polyphenols were determined by the Folin-Ciocalteu method [13]. In this study, the micro method cited by Waterhouse was applied [14]. $20 \mu \mathrm{L}$ of the extract was mixed with 100 $\mu \mathrm{L}$ of the Folin-Ciocalteu reagent and $1580 \mu \mathrm{L}$ of water. After $8 \mathrm{~min}, 300 \mu \mathrm{L}$ of $7.5 \%$ of sodium carbonate solution were added and the mixture was shaken a few seconds on the Vortex. The solution was kept at $25^{\circ} \mathrm{C}$ for $2 \mathrm{~h}$ and then the absorbance was measured at 767 nm (UV/Vis LAMBDA 25/35/45 Perkin-Elmer Spectrophotometer). Calibration solutions of gallic acid in the range of 0 to $24 \mathrm{mg} / \mathrm{L}$ were prepared and $100 \mu \mathrm{L}$ of each gallic acid solution $(0,2.4,4.8,7.2,12$ and $24 \mathrm{mg} / \mathrm{L})$ was used for the Folin-Ciocalteu test in the same way that cited previously. The absorbance was measured at $767 \mathrm{~nm}$ on each concentration of these calibration solutions. The total polyphenol content was calculated by using the standard curve 
equation $\left(A=0.0624 \mathrm{C}+0.0701\right.$, with $\mathrm{r}^{2}$ value of 9.9996) and expressed in milligram of gallic acid equivalent per dry matter of grape seeds (mg GAE $\left./ \mathrm{g}_{\mathrm{dm}}\right)$.

\subsection{Radical scavenging activity of extracts}

The Ahmeur Bouamer grape seed extracts obtained under the three extraction methods were subjected to antioxidant activity measurement analysis. 1,1-diphenyl-2-picrylhydrazyl $\left(\mathrm{DPPH}^{*}\right)$ and 2-2`Azinobis (3-ethylbenzothiazoline-6-sulphonic acid) diammonium salt $\left(\mathrm{ABTS}^{\cdot+}\right)$ radical scavenging assays were used to determine the radical scavenging activity of extracts.Percentage of inhibition was calculated using the following equation:

$$
\% \text { inhibition }=\left(1-\frac{A_{\text {EXTRACT }}}{A_{\text {ELANK }}}\right) \times 100
$$

With $\mathrm{A}_{\text {Blank }}$ absorbance of blank at initial time reaction and $\mathrm{A}_{\text {Extract }}$ absorbance of extract at reaction time.

\subsubsection{DPPH radical scavenging assay}

Antiradical activities were determined using the procedure as described by Brandwilliams et al. [15] with minor modifications. An aliquot of $25 \mu \mathrm{L}$ of extract was added to $975 \mu \mathrm{L}$ of DPPH solution (60 $\mu \mathrm{M}$ in ethanol) and vortexed for few seconds. The decrease absorbance at $517 \mathrm{~nm}$ was read continuously every $5 \mathrm{~min}$ by spectrophotometer until reaction reached the steady state. The kinetic reaction of each extract was determined and the antioxidant activity was calculated after an appropriate dilution.

\subsubsection{ABTS radical scavenging assay}

ABTS assay described by Francisco and Resurreccion [16] with some modifications was based on the relative ability of antioxidant to scavenge the radical $\mathrm{ABTS}^{.+}$which was resulted by the reaction of ABTS $(7 \mathrm{mM})$ with potassium persulphate $(2.45 \mathrm{mM})$. The mixture was left to stand in the dark at room temperature for $12-16 \mathrm{hrs}$ before use and the $\mathrm{ABTS}^{+}$solution was diluted with ethanol to a maximum absorbance of $0.80 \pm 0.02$ at $748 \mathrm{~nm}$. In the 6th minute after adding the sample to the $\mathrm{ABTS}^{{ }^{+}}$radical, the extract ability to scavenge the radical was determined by an absorbance measurement, at a wave length of $748 \mathrm{~nm}$. For the two assays, a standard curve drawn up for solutions of the synthetic vitamin E (Trolox) was used to calculate antioxidant capacity of each extract and the result was expressed as $\mu$ mol TE per 
gram of sample (dried matter).

\subsection{Statistical analysis}

The analyses were done in triplicate. Means and standard deviations of data were calculated. All figures were represented with error bars corresponding to the ratio of standard deviation (RSD).

\section{RESULTS AND DISCUSSION}

\subsection{Sieve analysis and dry matter content}

Different size portions collected after sieving and the average of $93.40 \pm 0.24 \%$ of dry matter content obtained from the grape seed powder have been illustrated on table 1 .

Table 1. Sieve analysis and dry matter content.

\begin{tabular}{lc}
\hline \multicolumn{2}{l}{ Sieve analysis } \\
\hline Size $(\mu \mathrm{m})$ & Size Portion $(\%)$ \\
\hline $\mathbf{5 0 0}$ & 36.65 \\
$\mathbf{5 0 0 - 3 5 5}$ & 20.04 \\
$\mathbf{3 5 5 - 1 8 0}$ & 36.80 \\
$\mathbf{1 0 0}$ & 4.19 \\
\hline Dry matter content(\%) & $\mathbf{9 3 . 4 0 \pm 0 . 2 4}$ \\
\hline
\end{tabular}

\subsection{Maceration}

\subsubsection{Determination of mixture solvent composition}

The change in composition of ethanol/water ratio provides a concentration of total polyphenols ranging from $36.83 \pm 0.47$ to $50.87 \pm 0.81 \mathrm{mg} \mathrm{GAE} / \mathrm{g}_{\mathrm{dm}}$ and the maximum obtained concentration of $50.87 \pm 0.81 \mathrm{mg} \mathrm{GAE} / \mathrm{g}_{\mathrm{dm}}$ is provided by the ratio $50 / 50$ $\mathrm{v} / \mathrm{v}$ ethanol/water (Fig.1A). This result is in agreement with the fact that the penetration in the hydrophobic areas of the seed matrix is facilitated and can help to precipitate soluble seed proteins as found in previous works [13].

\subsubsection{Determination of liquid/solid ratio}

For a fixed mixture of ethanol / water 50/50 v/v, the ratio L/S was varied from 10 to $40 \mathrm{~mL} / \mathrm{g}$. The obtained concentration of total polyphenols was ranged from $28.98 \pm 0.66$ to $78.20 \pm 0.48$ $\mathrm{mg} \mathrm{GAE} / \mathrm{g}_{\mathrm{dm}}$. The maximum concentration of total polyphenols was obtained with the ratio 
$20 \mathrm{~mL} / \mathrm{g}$ (Fig.1B).This concentration represents $7.82 \%(\mathrm{w} / \mathrm{w})$ of the total grape seeds and can be considered as a good yield compared to other works (6.68 \% for Bucic-Kojik and 3.92\% for Shi) [5,17], with the same solvent and the same mixture composition.
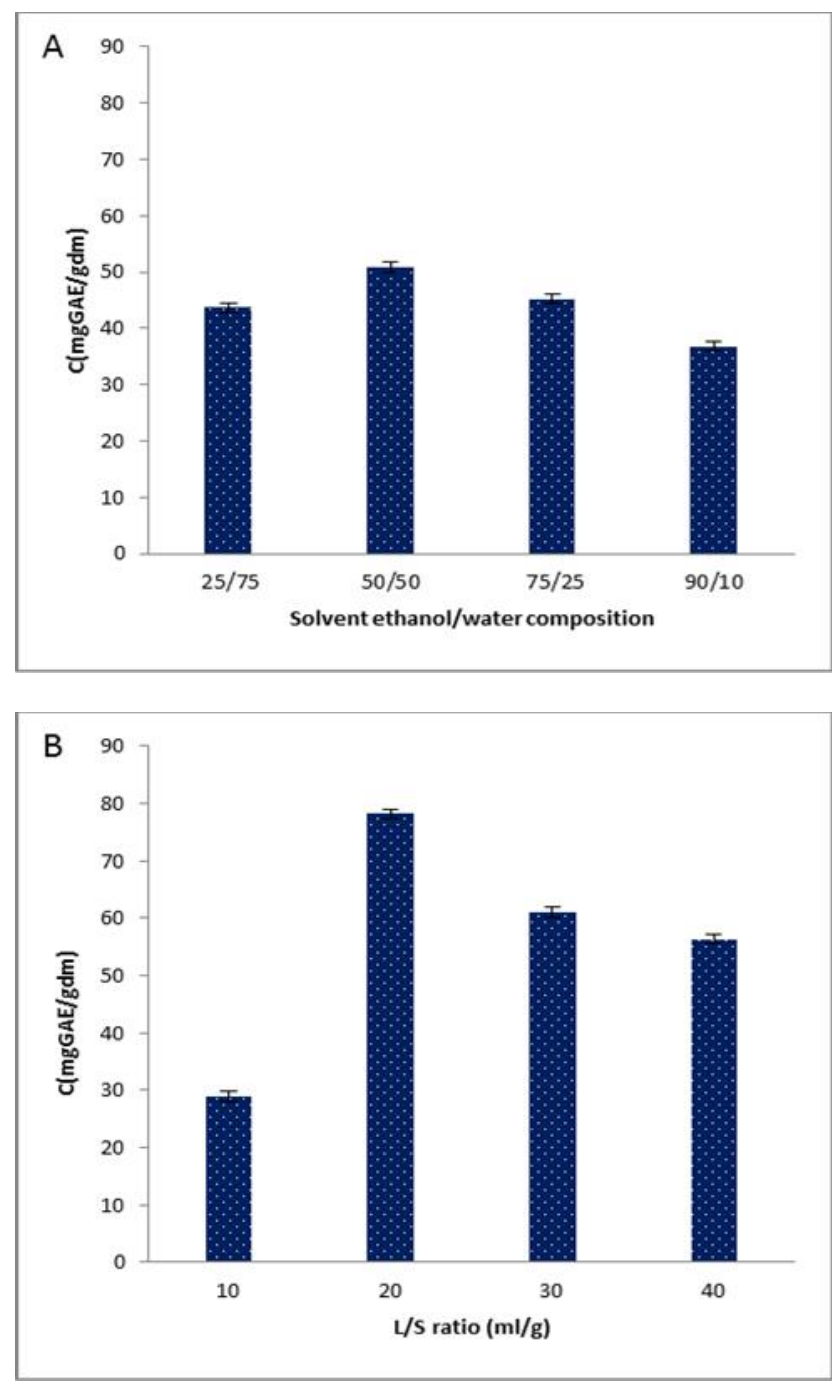

Fig.1. (A) Determination of mixture composition after $120 \mathrm{~min}$ at $25^{\circ} \mathrm{C}$, (B) Evaluation of liquid-solid ratio for particle size of $500-355 \mu \mathrm{m}$ after $120 \mathrm{~min}$ at $25^{\circ} \mathrm{C}$.

\subsubsection{Determination of particle size, temperature and time}

The results illustrate on Fig.2 revealed that whatever the time and the temperature, the amount of extracted polyphenols depends on the particle size of powder seeds. For the size $500 \mathrm{~m}$, the maximum concentration was $67.78 \pm 0.46 \mathrm{mg} \mathrm{GAE} / \mathrm{gdm}$ (Fig.2c), the size 500-355 m gave a maximum concentration of $90.95 \pm 0.24 \mathrm{mg}$ GAE/gdm (Fig.2c) while the highest concentration was obtained for the size 355-180 $\mu \mathrm{m}$ (114.82 $\pm 1.24 \mathrm{mg}$ GAE/gdm) (Fig.2a). 
These results corroborate those already found in previous works [13, 18].
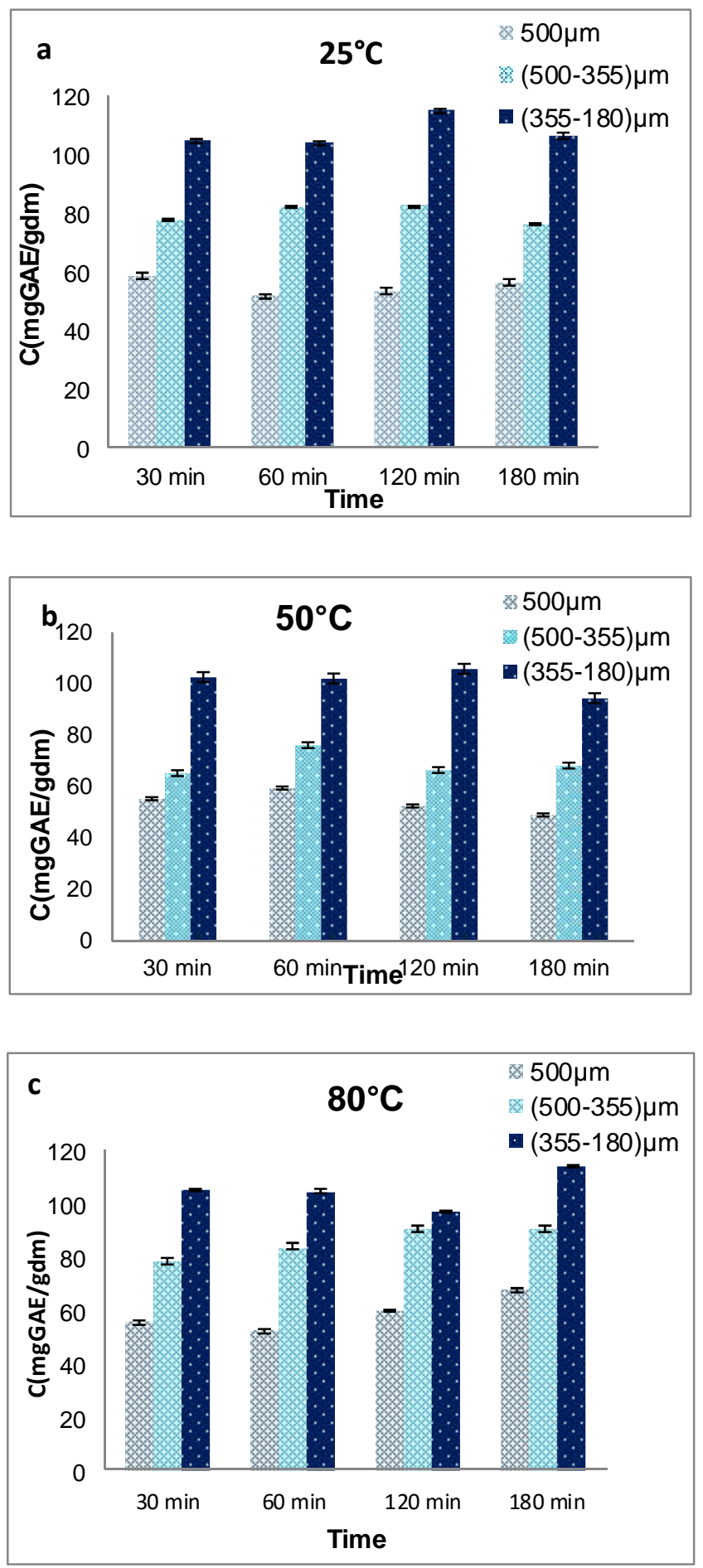

Fig.2. Effect of particle sizes on total polyphenols extraction, (a) at $25^{\circ} \mathrm{C}$, (b) at $50^{\circ} \mathrm{C},(\mathbf{c})$ at $80^{\circ} \mathrm{C}$. 
To understand the structural changes inherent in the extraction of polyphenols from secreting cells, SEM images (FEI quanta $200 \mathrm{feg}$ ) were recorded on the milled grape seeds of different particle sizes before and after extraction (Fig.3). Before extraction, at $500 \mathrm{~m}$, the grinding is superficial. Some blocks have an alveolar appearance, while others remain intact (fig.3 pictures 1). For 500-355 and 355-180 m, the alveolar aspect is clearly present (fig 3 picture 2 and 3), the secretory cells (as cavities) are different and depend on the ground material size. The variation in the extracted polyphenols quantity is directly related to the accessibility of polyphenol secretory cells. After extraction, the structural changes related to the extraction are mainly materialized by the presence of large cavities. Among the different particle sizes, it can distinguish changes in the depth of the pores (Fig. 3, pictures 4, 5 and 6). Moreover, by looking more closely to the cavities, it can observe that for the larger particles, some are closed (Fig.3, picture 4), while for the two other sizes (Fig. 3 picture 5 and 6), nearly all the cavities are open. The release of polyphenols present in the secretory cells depends on the accessibility to these cells, which is shallow for the size $500 \mathrm{~m}$ (Fig.3 picture 4) and deep for the two other sizes (Fig.3 pictures 5 and 6). The highest concentration of total polyphenols obtained for size 355-180 $\mu \mathrm{m}$ (114.82 $\pm 1.24 \mathrm{mg} \mathrm{GAE} / \mathrm{gdm}$, (Fig.2a)) can be explained by the fact that some cavities have been subjected to a cellular bursting which has released more polyphenols (Fig.3, picture 6c). A small difference has been noted between the concentrations found at $25^{\circ} \mathrm{C}$ and $120 \mathrm{~min}(114.82 \pm 1.24 \mathrm{mg} \mathrm{GAE} / \mathrm{gdm})$ and that found at $80^{\circ} \mathrm{C}$ and $180 \mathrm{~min}$ $(114.29 \pm 0.11 \mathrm{mg} \mathrm{GAE} / \mathrm{gdm})($ Fig 2). The time and the temperature parameters have no important effect on extraction with the variation of the particle size parameter. These findings were in agreement with those reported by Bucic - Kojic et al.[5]. 


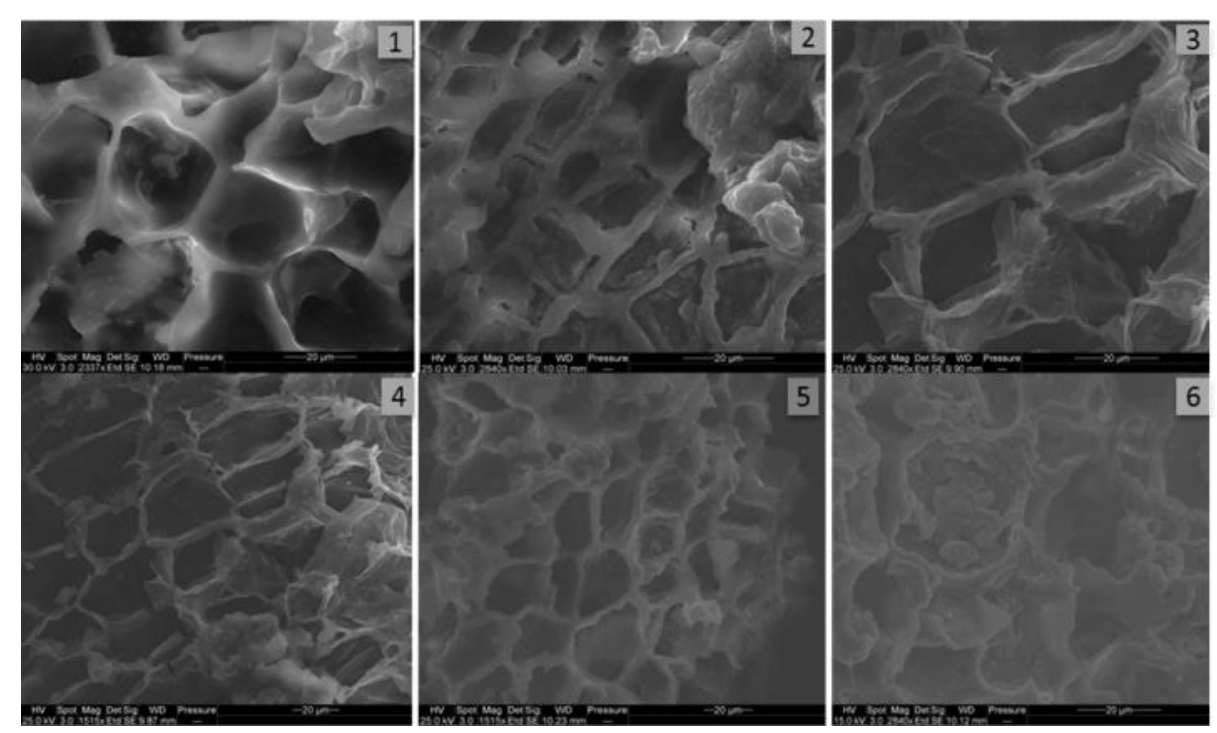

Fig.3. SEM pictures of powdered seeds of different particle sizes before extraction $1(>500 \mu \mathrm{m}), 2(500-355 \mu \mathrm{m})$ and $3(355-180 \mu \mathrm{m})$, after extraction $4(>500 \mu \mathrm{m})$, $5(500-355 \mu \mathrm{m})$ and $6(355-180 \mu \mathrm{m})$, SEM pictures sizes: $20 \mu \mathrm{m}$

\subsection{Effect of three extraction methods on the total polyphenols yield}

After optimised extraction parameters for ultrasound and microwave, the three methods (maceration, ultrasound and microwave) were compared under optimal conditions (powder seeds at $250 \mu \mathrm{m}, \mathrm{T}$ at $25^{\circ} \mathrm{C}$, extraction time between $5-60 \mathrm{~min}$ ).

\subsubsection{Ultrasound}

As illustrated in Fig.4, ultrasound extraction gives at $25^{\circ} \mathrm{C}$ the lowest amount of extracted polyphenols $\left(29.86 \pm 0.36 \mathrm{mg} \mathrm{GAE} / \mathrm{g}_{\mathrm{dm}}\right)$ after $5 \mathrm{~min}$. The maximum amount is obtained at 15 min and reaches $70.50 \pm 0.81 \mathrm{mg} \mathrm{GAE} / \mathrm{g}_{\mathrm{dm}}$ of total polyphenols. The concentration obtained at $30 \mathrm{~min}\left(50.95 \pm 0.89 \mathrm{mg} \mathrm{GAE} / \mathrm{g}_{\mathrm{dm}}\right)$ is similar to that obtained by Ghafoor et al, $(54.1 \pm 1.5 \mathrm{mg}$ $\left.\mathrm{GAE} / \mathrm{g}_{\mathrm{dm}}\right)$ but at a temperature of $56.03^{\circ} \mathrm{C}$ [19]. According to Usaquen-Castro et al., it is better to work at ambient temperature in order to preserve polyphenol compound from eventual degradation if a long exposure time is applied at high temperature $[20,21]$. These results corroborate this observation since a concentration of $7.05 \%(w / w)$ of the total grape seeds is reached in only $15 \mathrm{~min}$ at $25^{\circ} \mathrm{C}$.

\subsubsection{Microwave}

The results found by microwave extraction are significantly important. So, after $2.5 \mathrm{~min}$, the 
polyphenol concentration reached $183.36 \pm 0.53 \mathrm{mg} \mathrm{GAE} / \mathrm{g}_{\mathrm{dm}}$ (Fig.4), which is higher than those found by both maceration and ultrasound in their optimum time and temperature. The maximum value of $193.11 \pm 1.08 \mathrm{mg} \mathrm{GAE} / \mathrm{g}_{\mathrm{dm}}$ is obtained after $5 \mathrm{~min}$ and the lowest $(119.11$ $\pm 1.92 \mathrm{mg}$ GAE $/ \mathrm{g}_{\mathrm{dm}}$ ) after $60 \mathrm{~min}$ (Fig.4 microwave extraction). This decrease of total polyphenol concentration with the increase of the extraction time is in perfect agreement with the advantages of the microwave extraction reported by many previous research works [22]. The amount of total polyphenols decreases when the temperature increases from 193.11 $\pm 1.08 \mathrm{mg} \mathrm{GAE} / \mathrm{g}_{\mathrm{dm}}$ at $25^{\circ} \mathrm{C}$ to $139.13 \pm 1.59 \mathrm{mg} \mathrm{GAE} / \mathrm{g}_{\mathrm{dm}}$ at $50^{\circ} \mathrm{C}$ and finally $133.76 \pm 1.51$ $\mathrm{mg}$ GAE $/ \mathrm{g}_{\mathrm{dm}}$ at $80^{\circ} \mathrm{C}$. In this case, the use of microwave heating in open vessels has a little influence on the extraction when the temperature increases from $50^{\circ} \mathrm{C}$ to $80^{\circ} \mathrm{C}(139$ to $133 \mathrm{mg}$ $\mathrm{GAE} / \mathrm{g}_{\mathrm{dm}}$ ). This may be explained by the fact that a part of the solvent (ethanol/water) was directly heated, which reduces the extraction efficiency by the solvent evaporation if the temperature increases above its boiling point [23].This is not the case with closed vessels [22].

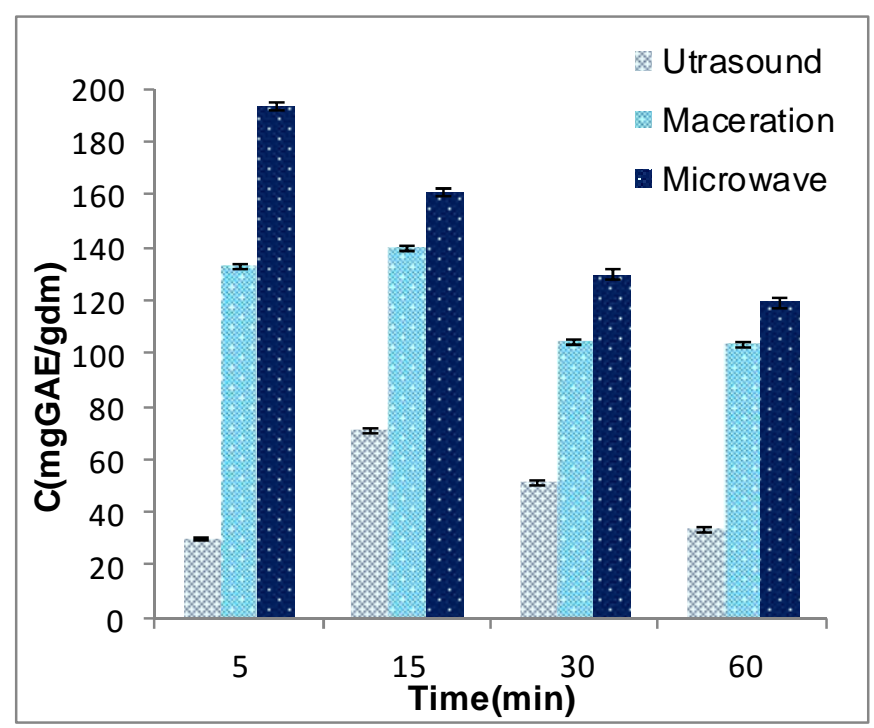

Fig. 4. Comparison between the three extraction methods at $25^{\circ} \mathrm{C}$.

\subsubsection{Comparison between the three extraction methods}

The amount of total polyphenols extracted by the microwave method was higher than that extracted by both maceration and ultrasound methods at each extraction time (Fig.4). For microwave extraction, the maximum amount of $193.11 \pm 1.08 \mathrm{mg} \mathrm{GAE} / \mathrm{g}_{\mathrm{dm}}$ was reached after $5 \mathrm{~min}$ while the maximum amounts of $139.93 \pm 1.51 \mathrm{mg} \mathrm{GAE} / \mathrm{g}_{\mathrm{dm}}$ and $70.50 \pm 0.89 \mathrm{mg}$ 
$\mathrm{GAE} / \mathrm{g}_{\mathrm{dm}}$ were obtained after $15 \mathrm{~min}$, for maceration and ultrasound methods respectively. These results were supported by the yields of the three extraction methods reported in Table 2 .

Table 2. Yields, Total polyphenols concentration and Antioxidant Activity of Grape seed extracts.

\begin{tabular}{|c|c|c|c|c|}
\hline Extracts & Yields \% & $\begin{array}{l}\text { TPC } \\
\left(\mathrm{mg} \mathrm{GAE} / \mathrm{g}_{\mathrm{dm}}\right)\end{array}$ & $\begin{array}{c}\text { DPPH } \\
\left(\mu \mathrm{mol} \mathrm{TE} / \mathrm{g}_{\mathrm{dm}}\right)\end{array}$ & $\begin{array}{l}\text { ABTS } \\
(\mu \mathrm{mol} \text { TE/gdm })\end{array}$ \\
\hline Mw 5min & $37.74 \pm 0.32$ & $193.11 \pm 1.08$ & $23.69 \pm 1.05$ & $4218.46 \pm 48.90$ \\
\hline Mac 15min & $14.16 \pm 0.15$ & $139.93 \pm 1.51$ & $17.84 \pm 2.02$ & $3902.27 \pm 32.66$ \\
\hline Us 15 min & $6.70 \pm 0.25$ & $70.50 \pm 0.89$ & ND & ND \\
\hline
\end{tabular}

\pm SD, Microwave extract (Mw $5 \mathrm{~min}$ ); Maceration extract (Mac $15 \mathrm{~min}$ ); Ultrasound extract (Us $15 \mathrm{~min}$ ); ND no determined

Higher concentrations of total polyphenols were obtained in this work for the three extraction methods, generally with a shorter time and a lower temperature, in comparison with those reported in literature (Table 3). For the extraction by maceration, Bucic-Kojic et al. found a concentration of $66.81 \pm 0.9 \mathrm{mg} \mathrm{GAE} / \mathrm{g}_{\mathrm{dm}}$ after $200 \mathrm{~min}$ at $80^{\circ} \mathrm{C}$ with particle size less than $630 \mu \mathrm{m}$ [5]. The same authors found $129.59 \pm 7.7 \mathrm{mg} \mathrm{GAE} / \mathrm{g}_{\mathrm{dm}}$ in the same condition of time and temperature but with particle size less than $560 \mu \mathrm{m}$ [6]. With the same particle size, a concentration of $130 \mathrm{mg} \mathrm{GAE} / \mathrm{g}_{\mathrm{dm}}$ has been recently found by Bucic-Kojic et al. after improving the mathematical model of the extraction kinetics [24]. Boussetta et al., reached a maximum concentration of $86 \pm 0.2 \mathrm{mg} \mathrm{GAE} / \mathrm{g}_{\mathrm{dm}}$ with particle size less than $400 \mu \mathrm{m}$ in only $15 \mathrm{~min}$ and at $50^{\circ} \mathrm{C}$ [25]. In this work, the grinding less than $250 \mu \mathrm{m}$ gives a concentration of $139.93 \pm 1.51 \mathrm{mg} \mathrm{GAE} / \mathrm{g}_{\mathrm{dm}}$ in only $15 \mathrm{~min}$ with a temperature of $25^{\circ} \mathrm{C}$. These are probably the good conditions to obtain a rich extract on polyphenols. So, it is important to note that a long heating at a high temperature can denature the phenolic compounds as cited by Usaquén-Castro et al. [20]. Regarding the difference between the results found by Ghafour et al. [19], for the ultrasound extraction $\left(54.1 \pm 1.5 \mathrm{mg} \mathrm{GAE} / \mathrm{g}_{\mathrm{dm}}\right.$ after $29.03 \mathrm{~min}$ and at $\left.56.30^{\circ} \mathrm{C}\right)$ and those obtained in this study $\left(70.50 \pm 0.89 \mathrm{mg} \mathrm{GAE} / \mathrm{g}_{\mathrm{dm}}\right.$ after $15 \mathrm{~min}$ and at $\left.25^{\circ} \mathrm{C}\right)$, it can 
be deduced that for the same reasons [20], the best extraction conditions are achieved with shorter time and less heating.

Table 3. Comparison of the best conditions for extraction of total polyphenols from grape seeds by different extraction methods.

\begin{tabular}{|c|c|c|c|c|c|c|c|}
\hline \multirow{2}{*}{$\begin{array}{l}\text { Extraction } \\
\text { method }\end{array}$} & \multicolumn{5}{|c|}{ Best extraction condition } & \multirow{2}{*}{$\begin{array}{c}{ }^{*} \mathrm{TPC} \\
\left(\mathrm{mgGAE} / \mathrm{g}_{\mathrm{dm}}\right)\end{array}$} & \multirow[t]{2}{*}{ Reference } \\
\hline & $\begin{array}{l}\text { Size } \\
(\mu \mathrm{m})\end{array}$ & $\begin{array}{c}\mathrm{L} / \mathrm{s} \\
(\mathrm{mL} / \mathrm{g})\end{array}$ & $\begin{array}{c}\text { Ethanol/water } \\
\text { (\%) }\end{array}$ & $\begin{array}{c}\text { Temperature } \\
\left({ }^{\circ} \mathrm{C}\right)\end{array}$ & $\begin{array}{l}\text { Time } \\
(\min )\end{array}$ & & \\
\hline Ultrasound & $<500$ & 50 & 53.15 & 56.03 & 29.03 & $54.1 \pm 1.5$ & $\begin{array}{c}\text { Ghafoor et al. } \\
2009\end{array}$ \\
\hline Ultrasound & $<250$ & 20 & 50 & 25 & 15 & $70.50 \pm 0.89$ & Present work \\
\hline Maceration & $<630$ & 40 & 50 & 80 & 200 & $66.81 \pm 0.9$ & $\begin{array}{c}\text { Bucic-Kojic et al. } \\
2007\end{array}$ \\
\hline Maceration & $<560$ & 40 & 50 & 80 & 200 & $129.59 \pm 7.7$ & $\begin{array}{c}\text { Bucic-Kojic et al. } \\
2009\end{array}$ \\
\hline Maceration & $<560$ & 40 & 50 & 80 & 200 & $130.2 \pm 1.4$ & $\begin{array}{c}\text { Bucic-Kojic et al. } \\
2013\end{array}$ \\
\hline Maceration & $<400$ & 5 & 50 & 60 & 15 & $90.0 \pm 0.2$ & $\begin{array}{c}\text { Boussetta et al. } \\
2012\end{array}$ \\
\hline Maceration & $<250$ & 20 & 50 & 25 & 15 & $139.93 \pm 1.51$ & Present work \\
\hline Microwave & unknown & 45.3 & 47.2 & 60 & 4.6 & $96.3 \pm 1.5$ & $\begin{array}{l}\text { Li et al. } \\
2011\end{array}$ \\
\hline Microwave & $<250$ & 20 & 50 & 25 & 5 & $193.11 \pm 1.08$ & Present work \\
\hline
\end{tabular}

* Total polyphenols concentration (TP) expressed by $\mathrm{mg}$ GAE/g $\mathrm{g}_{\mathrm{dm}}$, results were the average of three analysis and expressed as mean \pm SD

Concerning the microwave extraction, the value of $96.3 \pm 1.5 \mathrm{mg} \mathrm{GAE} / \mathrm{g}_{\mathrm{dm}}$ recently found by Li et al. [22], represents $50 \%$ of the concentration obtained in this study nearly in the same time of $4.6 \mathrm{~min}$. These authors have worked in closed vessels at $60^{\circ} \mathrm{C}$ and this parameter was known to increase the efficiency of extraction compared to the open vessels [26]. However, in this case, extraction was performed in both closed and open vessels in 5 min at $25^{\circ} \mathrm{C}$. The obtained concentrations in closed and open vessels were respectively $163.66 \pm 1.02 \mathrm{mg} \mathrm{GAE} /$ $\mathrm{g}_{\mathrm{dm}}$ and $159.35 \pm 1.24 \mathrm{GAE} \mathrm{mg} / \mathrm{g}_{\mathrm{dm}}$. This small difference of concentration suggests that the 
use of open /closed vessels has little influence on the microwave extraction at $25^{\circ} \mathrm{C}$.

\subsection{Radical scavenging activity of extracts}

All the grape seed powder extracts have exhibited an appreciable scavenging activity for the both methods (DPPH and $\mathrm{ABTS}^{+}$). For the DPPH test, the results of the kinetic reaction illustrated in Fig.5A indicate that the extracts present a reaction time (maximum of inhibition) of $30 \mathrm{~min}$. Moreover, the microwave and the maceration extracts exhibit more than $50 \%$ of DPPH inhibition, whereas for ultrasound extract, only $38 \%$ of DPPH inhibition was reached. Several dilutions were applied to the extracts (from 2 to 1000-fold dilutions), except for the extract obtained by microwave technique which exhibits more than $50 \%$ of DPPH inhibition after 10 dilutions, the rest of extracts present lower inhibition from 2 dilutions (Fig.5B).This result may be explained by the yield of microwave extraction $(37.74 \pm 0.32 \%)$ which is nearly three times higher than maceration yield $(14.16 \pm 0.15 \%)$ and five times higher than ultrasound $(6.70 \pm 0.25 \%)$. By $\mathrm{ABTS}^{+}$test (Fig. 5C), the same result was obtained. The extracts obtained by microwave and maceration exhibit strong radical scavenging activities (78.05\% and $72.30 \%$, respectively) whereas the ultrasound extract exhibit only $41.65 \%$ of ABTS inhibition. The comparison of the two tests indicates that higher inhibitions were obtained by ABTS test for the three extraction methods. These results corroborate those found by Floegela et al. [27] which reports that, for vegetables, fruits and beverages, ABTS inhibition is higher than DPPH inhibition. Regarding the reported results in Fig 5C, it can denote that all the extracts possess antioxidant activity higher than BHA and BHT at the concentration of $1 \mathrm{ppm}$. Both synthetic antioxidants used in food processing which the allowable daily intake (ADI) should not exceed 0.5 and $0.05 \mathrm{ppm}$ (BHA and BHT respectively) [28], present a risk for health and can be replaced by those naturally produced. 

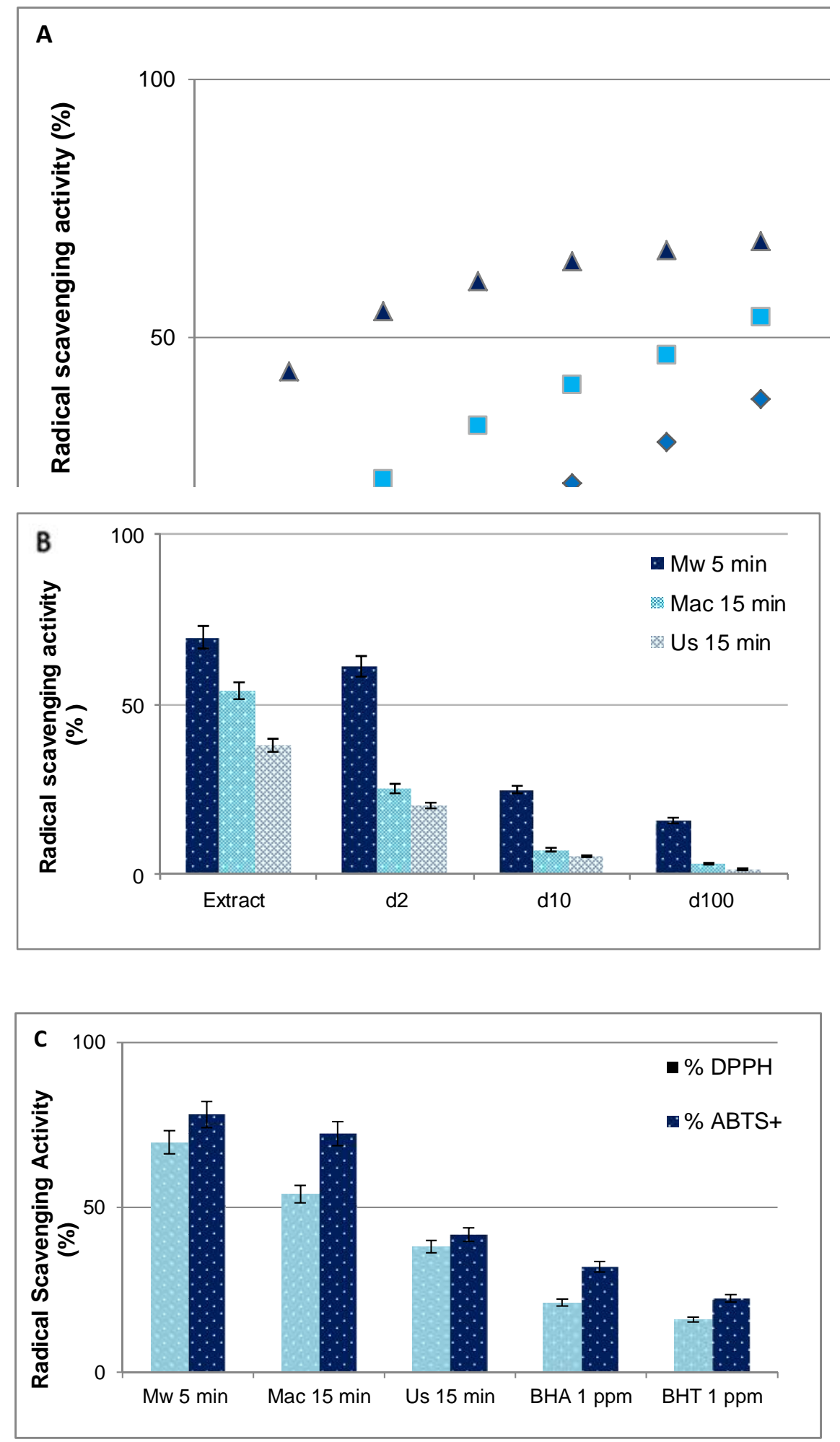

Fig. 5. (A). Kinetics of $\mathrm{DPPH}^{\bullet}$ reduction of extracts obtained by different extraction methods, (B). Radical scavenging activity at different extract dilution (from 2 to d1000-fold dilution) by DPPH method, $(\mathbf{C})$. Comparison of radical scavenging activity (DPPH and $\mathrm{ABTS}^{+}$assays) of extracts with BHA and BHT 


\section{CONCLUSION}

In conclusion, this present work has permitted to introduce for the first time the Algerian autochthonous variety Ahmeur Bouamer for the determination of total polyphenols from grape seeds. This study has allowed us to optimize the conditions and extraction methods to obtain important extraction yields of total polyphenols in comparison with previous works [5, $6,19,22,24$, and 25]. It's also important to note the positive influence of particle size parameter on the extraction yield, whatever the time and temperature of extraction. The extract which exhibit high radical scavenging activity is that obtained by microwave. This extraction method is a promising environment friendly technique for the obtaining of bioactive compounds from grape seeds which can be considered as a good source of natural and healthy compounds.

\section{ACKNOWLEDGEMENTS}

This work was financially supported by the Ministry of Higher Education and Scientific Research of Algeria, by the ARC (research contract AUWB- 2010-10/15-UMONS-5), FNRS and ENCITE programs and it was performed in the framework of COST TD 1004 and CM1006. The authors thank the Center for Microscopy and Molecular Imaging (CMMI, supported by the European Regional Development Fund and the Walloon Region) for their support. SEM images were achieved by M. Vermeersch, (Pr D.Perez-Morga, CMMI, Gosselies, Belgium) and microwave extraction was performed in the Pr P. Dubois laboratory, UMONS. Ahmeur Bouamer grapes were harvest with the collaboration of the Technological Institute of Fruit Arboriculture and Vine from Benchicao, Medea (Algeria).

\section{REFERENCES}

[1] Jayapraka-Sha G.K., Selvi T., Sakariah K.K. Antibacterial and antioxidant activities of grape seed extracts. Food Res Inter. 2003, 36, 117-122

[2] Nawaz H., Shi J., Mittal G.S., Kakuda Y. Extraction of polyphenols from grape seeds and concentration by ultrafiltration. Sep Pur Technol. 2006, 48, 176-181

[3] Ariga T. The antioxidative function, preventive action on disease and utilization of 
proanthocyanidins. Biofactors. 2004, 21, 197-201

[4] Pekié B., Kovac V., Alonso E., Revilla E. Study of the extraction of proanthocyanidins from grape seeds. Food Chem. 1998, 61, 201-206

[5] Bucic'-Kojic'A., Planinic ${ }^{M}$ M., Thomas S., Bilic ${ }^{\prime}$ M., Velic ${ }^{2} D$. Study of solid-liquid extraction kinetics of total polyphenols from grape seeds. J. Food Eng. 2007, 81, 236-242

[6] Bucic'-Kojic' A., Planinic' M., Tomas S., Jakobek L., Šeruga M. Influence of solvent and temperature on extraction of phenolic compounds from grape seed, antioxidant activity and color of extract. Inter J. Food Sci Technol. 2009, 44, 2394-2401

[7] Lin M.C., Tsai M.J., Wen K.C. Supercritical fluid extraction of flavonoids from Scutellariae Radix. J. Chromatogr A. 1999, 830, 387-395

[8] Palma M., Barroso C.G. Ultrasound-assisted extraction and determination of tartaric and malic acids from grapes and winemaking by-products. Anal Chim Acta. 2002, 458, 119-130

[9] Carrera C., Ruiz-Rodríguez A., Palma M.1., Barroso C.G. Ultrasound assisted extraction of phenolic compounds from grapes, Anal. Chim. Acta. 2012, 732, 100-104

[10] Sahli Z. Les produits du Terroir, les Indications Géographiques et le Développement Local Durable des Pays Méditerranéens. Options méditerranéennes: Serie A. 2009, n89, $305-338$

[11] Akkak A., Boccacci P., Lacombe T., Botta R. Relationships and genetic diversity of grapevine (Vitis vinifera L.) grown in Algeria and in Mediterranean Basin. pp 145-146. In: International Workshop on The role of biotechnology for the characterization and conservation of crop, forestry, animal and fishery genetic resources. 2000, March 5-7, Torino, Italy

[12] Turkmen N., Sedat VeliogluY., Sari F., Polat G. Effect of Extraction Conditions on Measured Total Polyphenol Contents and Antioxidant and Antibacterial Activities of Black Tea. Molecules.2007, 12, 484-496

[13] Singleton V.L., Orthofer R., Lamuela-Raventos R.M. Analysis of total phenols and other oxidation substrates and antioxidants by means of Folin-Ciocalteu reagent. Methods Enzymol. $1999,299,152-178$

[14] Waterhouse A.L. Determination of Total Polyphenols. Chap. I1.1.1- I1.1.8. In Current 
Protocols in Food.Anal Chem. Wrolstad, R.E.(Ed).2001, John Wiley and Sons Inc., New York

[15] Brandwilliams W., Cuvelier M.E., Berset C. Use of a free-radical method to evaluate antioxidant activity. LWT-Food. Sci. Technol. 1995, 28, 25-30

[16] Fransisco M.L.D.L and Resurrection A.V.A. Total phenolics and antioxidant capacity of heat treated peanut skin. J. Food Comp. Anal. 2009, 22, 16-24

[17] Shi J., Yu J., Pohorly J.,Young J.C.,Bryan M., Wu Y. Optimization of extraction of polyphenols from grape seed meal by aqueous ethanol solution. Food Agric Env. 2003, 1, 42-47

[18] Baydar N.G., Özkan G., Sagdiç O. Total phenolics contents and antibacterial activities of grape (Vitis vinifera L.) extracts. Food Control. 2004, 15, 335-339

[19] Ghafoor K., Choi Y.H., Jeon J.Y., Jo I.H. Optimization of ultrasound-assisted extraction of phenolic compounds, antioxidants and anthocyanins from grape (Vitis vinifera) seeds. J. Agric Food Chem. 2009, 57, 4988-4994

[20] Usaquén-Castro X., Martínez-Rubio M., Aya-Baquero H., González-Martínez G. Ultrasound-assisted extraction of polyphenols from red-grape (Vitis vinifera) residues. $13^{\text {th }}$ World Congress of Food Sciences Technology. 2006, 17/21 September, Nantes, France.

[21] Da Porto C., Porretto E., Decorti D. Comparison of ultrasound-assisted extraction with conventional extraction methods of oil and polyphenols from grape (Vitis vinifera L.) seeds. Ultrasonics Sonochemistry. 2013, 20, 1076-1080

[22] Li Y., Skouroumounis G.K., Elsey G.M., Taylor D.K. Microwave-assistance provides very rapid and efficient extraction of grape seed polyphenols. Food Chem. 2011, 129, 570-576

[23] Hui L., Bo C., Lihua N., Shouzhuo Y.. Solvent Effects on Focused Microwave Assisted Extraction of Polyphenolic Acids from Eucommia ulmodie. Phytochem. Anal. 2004, 15, 306-312

[24] Bucic'-Kojic'A., Sovova H., Planinic'M., Tomas S.. Temperature-dependent kinetics of grape seed phenolic compounds extraction: Experiment and model. Food Chem. 2013,136, 1136-1140

[25] Boussetta N., Vorobiev E., Le L.H., Cordin-Falcimaigne A., Lanoisellé J.L. Application 
of electrical treatments in alcoholic solvent for polyphenols extraction from grape seeds. Food Sci Technol. 2012, 46, 127-134

[26] Liazid A., Palma M., Brigui J., Barroso C.G. Investigation on phenolic compounds stability during microwave-assisted extraction. J. Chromatogr A. 2007, 114, 29-34

[27] Floegela A., Kimb D.O., Chungc S.J., Kooa S.I., Chuna O.K. Comparison of ABTS/DPPH assays to measure antioxidant capacity in popular antioxidant-rich US foods. J. Food Comp Anal. 2011, 24, 1043-1048

[28] Codex Alimentarius Commission (a), 1A, section 5, additifs alimentaires (1999)

\section{How to cite this article:}

Ghouila Z. Laurent S. Henoumont C. Vander Elst L. Muller N.R and Baaliouameur A. Rich Extract on Total Polyphenols and Antioxidant Activity Obtained By Conventional and Non-Conventional Methods from Ahmeur Bouamer Grape Seed. J. Fundam. Appl. Sci., 2016, 8(3), 692-711. 